\title{
鉄わよびたん白欠乏が成長期ラットの血色素量 および蔵器中鉄含量におよぼす影響†
}

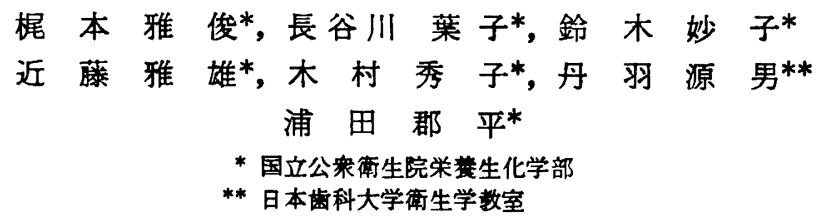

\author{
Effect of Iron and Protein Deficiency on Hemoglobin Content, \\ Hematocrit, Reticulocytes and Tissue Iron Levels \\ of Growing Rats \\ Masatoshi KAJIMOTO,* Yoko HASEGAWA,* Taeko SUZUKI,* \\ Masao KONDO,* Hideko KIMURA,* Motoo NIWA,** \\ Gumpei URATA* \\ * Department of Nutrition and Biochemistry, Institute of Public Health, Minato-ku, Tokyo \\ ** Department of Hygiene, Nippon Dental University Tokyo, Chiyoda-ku, Tokyo
}

The effect of dietary iron and/or protein deficiency on hemoglobin synthesis in growing rats has been investigated. Fifty-five female rats of the Donryu strain aged 3 weeks were divided into two groups and assigned diets supplemented with $20 \%$ or $5 \%$ casein. Each group was further divided into two groups, control and iron-deficient diet groups. The animals were maintained on these diets for three weeks, during which period body weight were recorded and blood samples were drawn in quantities of about $100 \mu l$ via the tail vein for determination of the hemoglobin concentration ( $\mathrm{Hb}$ ), hematocrit $(\mathrm{Ht})$, reticulocyte count and plasma protein content at weekly intervals. At the conclusion of the three-week observation period, some of the animals in each group were sacrificed by exsanguination via the axillary vein and the spleen, and liver tissue assayed for iron. Remainders in these group were fed thereafter on diets supplemented with iron or protein for a week to ascertain recovery from the dietary deficiencies. The following results were obtained:

1. Rats on the iron-deficient diets showed no appreciable change in weight gain from the respective control groups.

2. There were significant decreases in $\mathrm{Hb}$ and $\mathrm{Ht}$ of the rats fed on the iron-deficient diet with $20 \%$ casein as compared to the control group, whereas those maintained on the iron-deficient diet with $5 \%$ casein did not show any depression for these hematologic parameters. No significant intergroup differences were noted as to mean corpuscular hemoglobin concentration (MCHC).

3. The plasma and liver iron levels were lowest in the group on the iron deficient diet supplemented with $20 \%$ casein and the plasma iron level tend to be increased in the group on the diet with $5 \%$ casein supplementation.

4. The reticulocyte count decreased progressively in the growing rats. The iron-deficient diet

\footnotetext{
†鉄およびたん白欠乏が成長期ラットの血色案合

成におよぼす影曾（第1 報）

Effect of Iron and Protein Deficiency of

Hematopoiesis in Growing Rats (Part 1)

* 平108 東京都港区白金台 4-6-1

** 个102 東京都千代田区富士見 1-9-20
} 
group receiving $20 \%$ casein exhibited a rise in peripheral blood reticulocyte count and this trend was enhanced by dietary supplementation with iron. Dietary iron had on influence upon the reticulocyte count in the groups receiving $5 \%$ casein in feed, which showed elevation of reticulocyte count by administraion of $20 \%$ casein diet.

(Received August 14, 1980)

ヒトの栄堎性貝血は妊㖊と幼児に非常に多く, その大 部分は铁欠乏性貸血であるといわれている。哺釈動物に おいて，鉄が久そすると血色粂の合成が低下し傎血をお こすことはよく知られており，これまで多くの成贯(1)〜5)

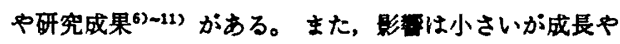
たん白欠乏によっても貸血がおこり，クワシオコールや マラスムスです資血がみられるが(2) 20)，一方，たん白 単独またはたん白と铁の同時欠乏では，発育中栄若状態 に重大な障害がみられるにるかかからず共血はそれ注ど 大きくなく，ときには血中の一モグロビンが正常に近い るのが報告されている(2) -13)。吉野ら 低たん白摄取と同時に鉄欠乏実倹を行なった結果，対照 の铁欠乏群より鉄吸収が覀かったにるかかわらず顀血の

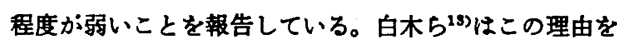
低たん白食による赤血球の寿命延長で説明している。著 者らはこの愎雓な機作を解明するため本研究において, 吉野，白木らと同じ $5 \%$ たん白の条件で幼若ラットを飼 育し，体重增加，血色亲量，へマトクリット，網赤血球

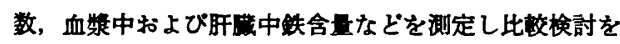
行なった。次いで鉄またはたん白を投与して，その回復 を現察し興味ある結果を得たので報告する。

\section{実 験 方 法}

\section{1. 实路旌物}

生後 3 週跲の䊒ドンリニーラット (SPF) 55 匹を日本 ラットより䝮入したるのを用いた。

\section{2 料}

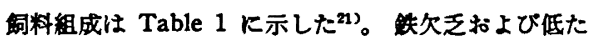

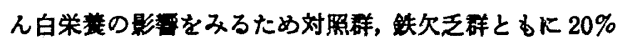
と $5 \%$ のカゼイン铝料を用いた。詞料はすへて等カロリ 一とするためカゼインのかわりにショ寒を增隇すること によりカロリー調節を行なった。鉄欠乏群飼料は塩混合 よりクエン酸鉄を除いたるのを使用した。また実絤期間 中の給佴量はすべて $12 \mathrm{~g}$ とした。

\section{3. 飼帝条件}

ラットは $23^{\circ} \mathrm{C} \pm 1^{\circ} \mathrm{C}$ の铜青室内にてアルミ製のヶー シ $(15 \times 30 \times 25 \mathrm{~cm})$ 飞 1 匹ずつ入れ，個別に䀦育し，毎 日定時に飼料および站料水(蒸留水)を交換した。饮料水 は自由に撕取させた。入荷後 5 日間は Table 1 に示し た $20 \%$ カセインン飼料を与え予備飼育した後, 平均体重 がほ活相等しくなるよらに群分けして央跧を開始した。

\section{4. 实験の群分け}

実験過程は Fig. 1 に示した。馿化期間として $20 \%$ カ ゼイン食ですぺてのラットを 5 日間予借飼育し，1群 5 匹ずつ計 11 群に分けた。これらのらち1群を飼育開始 群とし, 残り 10 群については $20 \%$ カゼイン群と $5 \%$ カ ゼイン群に分けた。20\%カゼイン群については，さらに 奶照群を 2 群, 鉃欠乏群を 2 群に分け, 3 週間飼育後, 铁欠乏群について 1 週間の鉄回復を試みだ。 $5 \%$ カゼイ ン群については対照群を 3 群, 鉄欠乏群を 3 群に分け,

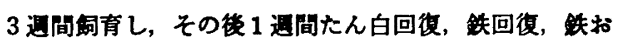
よびたん白回復を試みた。

\section{5. 則定項目およひ珝定方法}

飼育期間中, 毎遇 1 回体重湘定の注か尾㬹脈上り約 $0.1 \mathrm{ml}$ 採血し, へモクロビン (Hb) をシフンメトーモ

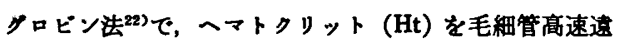
心法で測定し，血策たん白を日立屈折たん白計を用い， また網赤血球数は桐赤血球染色用ガラス毛細管キャピ口

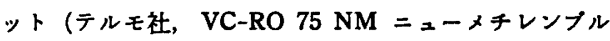
一) を使用し計数した。実敇開始後 Fig. 1 で示すよう に0，3，4 週目でラットの一部を腋下採血屠殺し, 尾 静脈血と同様の揤定を行なった。

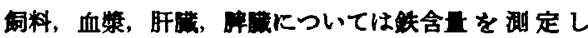

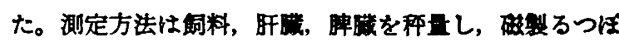
に入れ $80^{\circ} \mathrm{C}, 48$ 時間摬燥後科量し, 電気炬にて $550^{\circ} \mathrm{C}$,

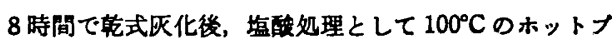

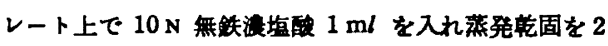
回行ない，最後に $0.1 \mathrm{~N}$ 塩酸でこれを $10 \mathrm{ml}$ Kして原 子吸光分析装屋(パリフンテクトロン社製モデル 100)を 用い $\mathrm{D}_{2}$ ランブハックグラウンド補正により测定した。 血撃鉄はハンフェナンスロリンを用いる方法によって剆 定した23)。

\section{実 臨 結 果}

\section{1. 体}

Fig. 2 に体重の測定結果を示した。20\%カゼイン対 照群, 铁欠乏群とすに加跲に伴い体重增加を示した。し かし铁欠乏による差は現われなかった。摄食量は Table 2 に示した。5\%カセインの対照, 鉄欠乏两群は $20 \%$ 群に比へ掑良早がやや低く，体重は飼育周始時と比へて ほとんど増加せず，また鉄投与して回復させてす体重は 增加しなかった。しかし 3 週後に $20 \%$ カゼンンを投与 
Table 1. Composition of experimental diet.

$(\mathrm{g} / 100 \mathrm{~g})$

\begin{tabular}{lccccc}
\hline \multirow{2}{*}{ Protein } & \multicolumn{2}{c}{$5 \%$} & & \multicolumn{2}{c}{$20 \%$} \\
\cline { 2 - 3 } \cline { 5 - 6 } & Control & Iron deficient & & Control & Iron deficient \\
\hline Casein & 5 & 5 & & 20 & 20 \\
Corn starch & 10 & 10 & & 10 & 10 \\
Sucrose & 70 & 70 & & 55 & 55 \\
Soy bean oil & 10 & 10 & & 10 & 10 \\
Salt mixtures) & 5 & $5^{*}$ & & 5 & $5^{*}$ \\
Vitamin mixtureb)** & $* *$ & $* *$ & $* *$ & $* *$ \\
\hline \hline
\end{tabular}

s) Composition (mg/100g diet): $\mathrm{NaCl}, 1253 ; \mathrm{KI}, 0.025 ; \mathrm{KH}_{2} \mathrm{PO}_{4}, 1715.5 ; \mathrm{CaHPO}_{4} \cdot 2 \mathrm{H}_{2} \mathrm{O}, 21.5$; $\mathrm{CaCO}_{3}$, [1464.5; $\mathrm{MgSO}_{4} \cdot 7 \mathrm{H}_{2} \mathrm{O}, 499 ; \mathrm{FeC}_{6} \mathrm{H}_{5} \mathrm{O}_{7} \cdot 6 \mathrm{H}_{2} \mathrm{O}, 31.15 ; \mathrm{CuSO}_{4} \cdot 5 \mathrm{H}_{8} \mathrm{O}, 7.80 ; \mathrm{ZnCl}_{2}, 1.00$; $\mathrm{MnSO}_{4} \cdot \mathrm{H}_{2} \mathrm{O}, 6.05 ;\left(\mathrm{NH}_{4}\right)_{6} \mathrm{MO}_{7} \mathrm{O}_{2} \cdot 4 \mathrm{H}_{2} \mathrm{O}, 0.125$.

b)** Composition (mg $/ 100 \mathrm{~g} \mathrm{diet}$ ) : thiamin, 0.5 ; riboflavin, 0.8 ; pyridoxine, 0.5 ; nicotinic acid, 4.0 ; $p$-Ca-pantothenate, 4.0 ; folic acid, 0.4 ; cyanocoblamin, 0.003 ; biotin, 0.04 ; myoinositol, $10 ; p$ amino-benzoic acid 10; choline, 200; retinol, $1000 \mathrm{IU}$; ergocalciferol, $100 \mathrm{IU}$; $\alpha$-tocopherol, 4; menaquinone, 0.5 .

* Iron was omitted from salt mixture. (less than $2.0 \mu \mathrm{g}$ iron $/ \mathrm{g}$ diet).

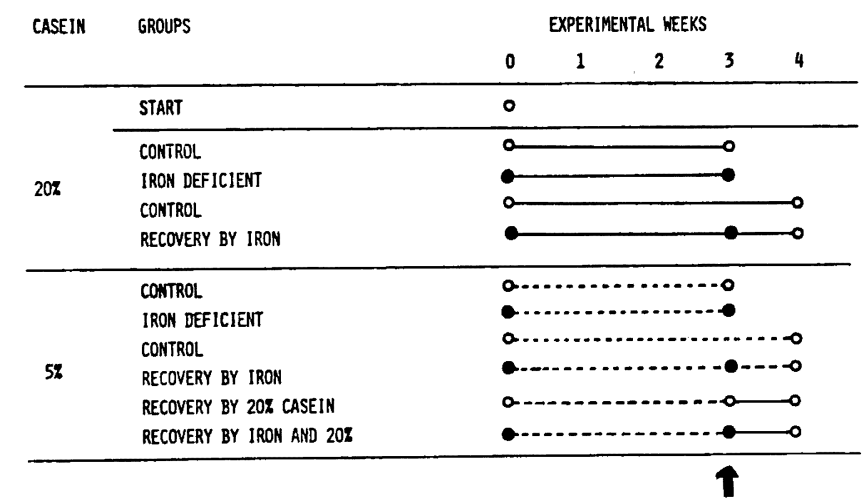

Fig. 1. Experimental schedule and dietary protein level.

$-0-0,20 \%$ casein, control; - $-20 \%$ casein, iron deficient; - - $0,20 \%$ casein, iron deficient, changed to $20 \%$ casein, control; $\cdots \circ \cdots \circ, 5 \%$ casein, control; $\cdots \circ \cdots \circ, 5 \%$ casein, control, changed to $20 \%$ casein, control; $\cdots \bullet \bullet, 5 \%$ casein, iron deficient; $\cdots \bullet \cdots, 5 \%$ casein, iron deficient, changed to $5 \%$ casein, control ; $\cdots \bullet-0,5 \%$ casein, iron deficient, changed to $20 \%$ casein, control. The arrow indicates the time of dietary change.

した対照群, 鉄と $20 \%$ カゼイン投与による回復群では 急激な体重増加を示し, 影著な体重增加が認められた。

\section{2. 血㝥たん白兵}

Fig. 3 飞血洯たん白の変動を示した。20\% カゼイン 群は, 対照群, 敛欠乏群とる上㫒を示した。 $5 \%$ カゼイ ン群は $20 \%$ カゼイン群より明らかに低下しているが, 4 週目の鉄および $20 \%$ カゼイン投与による回復によっ
て体重と同槏に急潄な增加を示した。

3. Hb 仕, Ht 值および Hb/Ht (MCHC)

Fig. 4 は $\mathrm{Hb}$ 值の值の経過で, 20\% 対照群はゆるゃ かに上早したのに対し，鉄欠乏群が加鸰とともに低下し たが，鉄投与により上昇した。5\%の両群はともに 1 週 目で上昇，3週目で低下し，鉄欠乏による Hb 值の差は 認められなかった。また 3 週後に $20 \%$ カゼイン，鉄と 
Table 2. Food intake (g/rat/day).

\begin{tabular}{llcccc}
\hline \multirow{2}{*}{$\begin{array}{c}\text { Casein } \\
(\%)\end{array}$} & \multicolumn{1}{c}{ Groups } & \multicolumn{4}{c}{ Experimental period } \\
\cline { 3 - 5 } & & 1 week & 2 weeks & 3 weeks & 4 weeks \\
\hline \multirow{2}{*}{20} & Control & 10.2 & $12.0 \pm 0$ & $12.0 \pm 0$ & - \\
& Iron deficient & 10.4 & $12.0 \pm 0$ & $12.0 \pm 0$ & - \\
& Control & 10.4 & $10.9 \pm 2.4$ & $10.2 \pm 1.7$ & $12.0 \pm 0$ \\
& Recovery by iron & 8.6 & $12.0 \pm 0$ & $12.0 \pm 0$ & $12.0 \pm 0$ \\
\hline \multirow{2}{*}{5} & Control* & 7.2 & $7.3 \pm 1.4$ & $7.4 \pm 0.8$ & - \\
& Iron deficient* & 7.6 & $6.5 \pm 2.4$ & $7.3 \pm 2.8$ & - \\
& Control* & 7.6 & $5.8 \pm 1.6$ & $8.5 \pm 2.2$ & $9.5 \pm 1.8$ \\
& Recovery by iron* & 7.4 & $5.1 \pm 2.1$ & $6.4 \pm 3.2$ & $9.0 \pm 2.1$ \\
& Recovery by 20\% casein & 4.7 & 7.0 & 6.1 & 8.2 \\
& Recovery by iron and 20\% & 4.6 & 5.5 & 7.7 & 8.6 \\
\hline
\end{tabular}

$12 \mathrm{~g}$ of Diet was surved for each rat per day. Values represent mean \pm S.D. of 5 rats per group.

* Significantly diff erent from corresponding value for $20 \%$ casein group $(p<0.05)$.

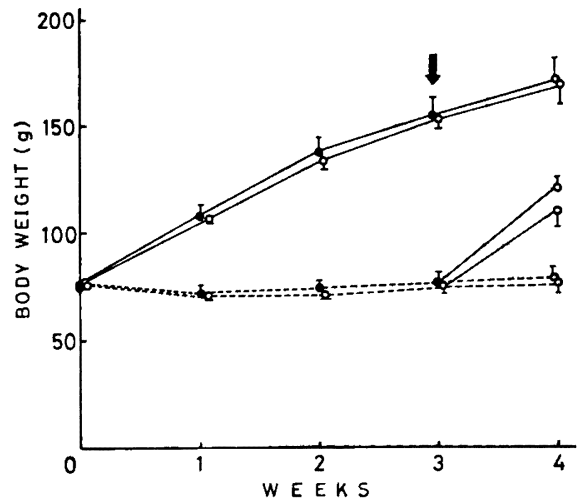

Fig. 2. Effect of dietary protein level and iron deficiency on growth of rats.

The meaning of marks are described in legend of Fig. 1. Vertical lines represent standard deviation of mean. The arrow indicates the time of dietary change.

20\% カゼイン投与による回復群における Hb 值は, 両 群ともに氛育閏始時の值にもどった。

Fig. 5(a) K Ht 値を示した。20\%対照群に比へて鉄 欠乏群は有意に低下しており，鉄投与の回復 1 週後で初 期値にもどった。 $5 \%$ 群で两群ともに1週で上早した が，3週で低下した。また，対照群と铁欠乏群には差が なかった。5\%鉄投与による回復です大きな変化はみら れなかったが，20\% カセイン投与による回復では対照 群，铁欠乏群とも铝育网始時と同値まで低下した。すな わち， 5, 20\% 群とも飞 Ht 值の変劧は $\mathrm{Hb}$ 值とほぼ

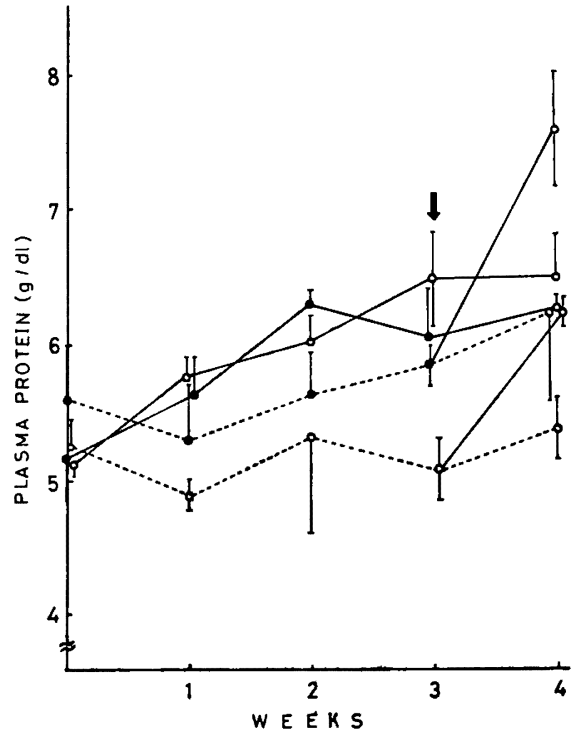

Fig. 3. Effect of dietary protein level and iron deficiency on plasma protein level of rats.

The meaning of marks are described in legend of Fig. 1. Vertical lines represent standard deviation of mean. The arrow indicates the time of dietary change.

同じパターンを示した。

Fig. 5(b) は Ht 值と Hb 值から MCHC を敦算し た結果で知欠乏群には等色意係数性の低下がみられなか った。 


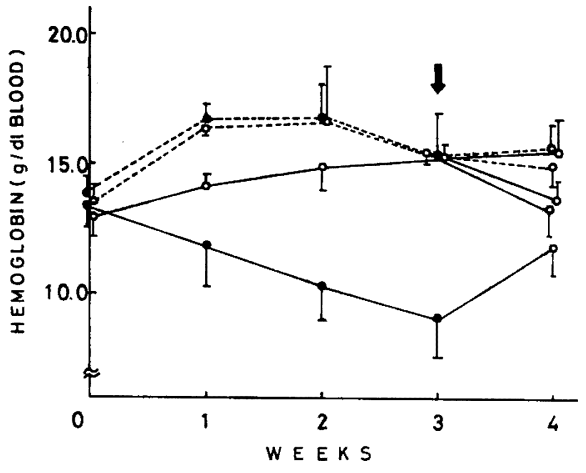

Fig. 4. Effect of dietary protein level and iron deficiency on blood hemoglobin level of rats.

The meaning of marks are described in legend of Fig. 1. Vertical lines represent standard deviation of mean. The arrow indicates the time of dietary change.

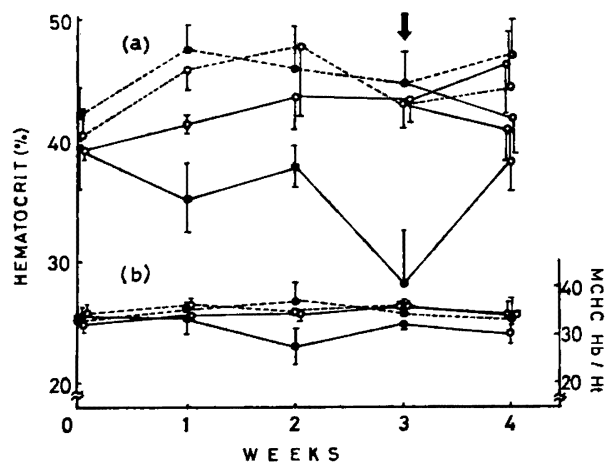

Fig. 5. Effect of protein level and iron deficiency on hematocrit and $\mathrm{MCHC}$ of rats.

The meaning of marks are described in legend of Fig. 1. Vertical lines represent standard deviation of mean. The arrow indicates the time of dietary change.

\section{4. 浻赤血球数}

Fig. 6 に示す粡赤血球数は加蛉とともに急速に低下 した。20\% カゼイン食の敛欠乏群は対照群に比へ增加 し，1 週間の铁投与ではさらに上早した。5\%カゼイン 群は一時低下後, 渐次增加し铁欠乏あるいは铁投与の影 票は少なく，20\% カゼイン投与で対照群，铁欠乏群と あに急上㫒した。

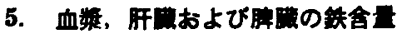

Table 3 に含鉄量の測定值を示した。血䠌鉄は $20 \%$ カゼイン食の加哈ではあまり変化はないが铁欠乏で低下

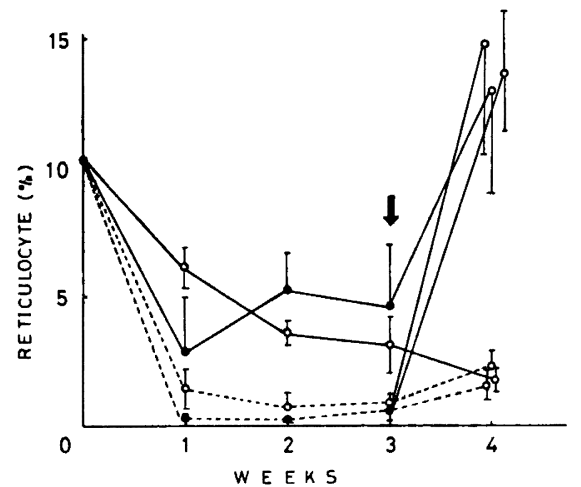

Fig. 6. Effect of dietary protein level and iron deficiency on reticulocyte count of rats.

The meaning of marks are described in legend of Fig. 1. Vertical lines represent standard deviation of mean. The arrow indicated the time of dietary change.

する傎向を示し，铁投与で上㫒を示した。 $5 \%$ \%ガイン 群ではやや上昇する傾向があり，铁投与やたん白投与で 対照值にすどった。

䀒鉄含量は加踰に伴い増加し鉄欠乏で低下した。この 低下の程度は $20 \%$ カゼイン群に大きかった。また铁投 与によって大きな変化はなく, 5 \% カゼインか 20\% カゼインへの切りがで有意に低下した。

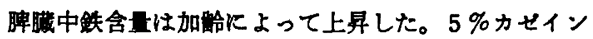
群は高い傾向にあり，铁欠乏では両群とす低下したが， $5 \%$ 群は高かった。铁あるいはたん白による回復で㤌あ まり上畀しなかった。

$$
\text { 考察 }
$$

铁欠乏性食血は妊嬬，幼児，成長期に多くみられ，失 投与によって改善されるが，铁吸収率が食棏構成によっ て異なり，とくにたん白栄㱳が問題となっている2(3) 27)。 この実験ではとくにヒトの铁欠乏モデルとしての考え はないが，実䀫系恃成長期における铁欠乏実跧であると いらことが重要であろう。動物に招ける铁出納と貸血の 闺連には三つの因子が考えられ，へモグロビン生成のた め铁の摄取量 ${ }^{25)}$ ，铁の損失，渴管からの吸收26) 26) があ げられる。著者らはこれら因子のらら铁の撕取甼たけけを とりあげこれにたん白栄琵が舆終的にどらいら結果を あたらすかをみている。

Fig. 2 により体重増加には，この条件下てたた白の効 果が大きく牫存铁て十分成長できるよらである。このこ とは铁欠乏群はかなりの程度の貣血があっても正常な成 曼ができることを急味している。また Fig. 2 で5\%の 
Table 3. Effect of iron and protein deficiency on iron content in various organs.

\begin{tabular}{llccccc}
\hline $\begin{array}{c}\text { Casein } \\
(\%)\end{array}$ & Groups & $\begin{array}{c}\text { Age } \\
(\text { weeks })\end{array}$ & $\begin{array}{c}\text { Periods } \\
(\text { weeks) }\end{array}$ & $\begin{array}{c}\text { Plasma } \\
(\mathrm{ppm})\end{array}$ & $\begin{array}{c}\text { Liver } \\
(\mathrm{ppm} / \mathrm{dry} \text { g) }\end{array}$ & $\begin{array}{c}\text { Spleen } \\
\text { (ppm/dry g) }\end{array}$ \\
\hline Start & 3 & 0 & $6.37 \pm 1.13$ & $245 \pm 90.3$ & $586 \pm 68$ \\
\hline 20 & Control & 6 & 3 & $3.51 \pm 1.30$ & $459 \pm 30.1$ & $629 \pm 29$ \\
& Iron deficient & 6 & 3 & $2.11 \pm 0.90$ & $180 \pm 34.5$ & $366 \pm 78$ \\
& Control & 7 & 4 & $3.19 \pm 0.62$ & $414 \pm 94.7$ & $838 \pm 159$ \\
& Recovery by iron & 7 & 1 & $0.79 \pm 0.18$ & $146 \pm 30.4$ & $493 \pm 71$ \\
\hline \multirow{2}{*}{5} & Control & 6 & 3 & $6.14 \pm 1.43^{*}$ & $422 \pm 75.3$ & $960 \pm 104^{*}$ \\
& Iron deficient & 6 & 3 & $3.72 \pm 1.01^{*}$ & $388 \pm 58.5^{*}$ & $709 \pm 192^{*}$ \\
& Control & 7 & 4 & $3.32 \pm 0.19$ & $400 \pm 68.0$ & $1,308 \pm 564$ \\
& Recovery by iron & 7 & 1 & $1.76 \pm 1.97^{*}$ & $221 \pm 19.5^{*}$ & $644 \pm 175$ \\
& Recovery by 20\% casein & 7 & 1 & $4.05 \pm 1.03$ & $283 \pm 115.9$ & $472 \pm 150$ \\
& Recovery by iron and 20\% & 7 & 1 & $4.77 \pm 0.90$ & $181 \pm 21.3$ & $491 \pm 167$ \\
\hline \hline
\end{tabular}

Values represent mean \pm S.D. of 5 rats per group.

* Significantly different from corresponding value for $20 \%$ casein group $(p<0.05)$.

低たん白によって3 週間飼育後, $20 \%$ カゼインに切り かえるだけで $20 \%$ の成長曲線よりる強い立ち上がりを 示すことは, $5 \%$ 群のたん白利用効率, いわゆる (PER) のよいことを示している。これは Fig. 3 の血漿たん白 をみてる明白である。次いで鉄欠乏群の血獎たん白がや や高い傾向を示したが, この理由はよくわからない。へモ クロピン, ヘマトクリット值でみると $5 \%$ 群は鉄の有無 にかかからず $1 \sim 2$ 週に上昇の傾向を示している。この 理由について白木ら ${ }^{28) \sim 32)}$ の, 低たん白で貟血がおこり にくいのは, 低たん白食では体液の濩縮と赤血球膜の脆 弱性が低下するといら説によって説明できる。したがっ て, この結果の解秎は成長の阻止による体液の湿縮が考 えられる。つぎに，20\% カゼン群に貧血があり鉄欠 乏の影䇾を強く現わしているのに対し，5\%では貧血が 現われない。一方，無制限に食事中の鉄やたん白のレベ ルを上け゚てす体重增加や血中へモグロビンは一定の値を 示すことが知られているので, 生体内の血球合成や破壞 の機構す，やはりたん白栄姜の影警をらけていると考え ざるをえない。これは Fig. 4，6 に示すように5\%カゼ インでは網赤血球数が低いにもかかわらず数週間たって もへモグロビン値が低下していないこと，つまり造血能 が低下しているにあかかわらず顀血をおこさないことか ら，低たん白で血球破壞が低下しているのであろう。こ こで, 低たん白で赤血球膜の浸透圧抵抗の脆弱性が低下 するといら報告33) するから，どちらの因子の影零が大 きいかは今後の課題である。Fig. 5 では，20\% 鉄欠の 2週間後で MCHCつまり血球一定容量に対するへモク ロビン量はやや低下しているが，他はほとんど变化して いないので強い鉄欠乏性貧血の特徽である低色素性䆩血
にはまだ至っていないと考えられる。この $5 \%$ \%ん白で は鉄欠乏性貧血がおこらない理由として, 吉野ら 長停止によって実験開始期における眝蔵鉄 ${ }^{34)}$ の利用であ ると説明している。Fig. 6 の網赤血球の変動をみると， $20 \%$ た白の鉄欠乏で 1 週間後一時低下して上开してい る。また低たん白食 1 週で鉄の有無にかかわらず網赤血 球数は急激に低下したが，その後の貧血はみられなかっ た。 $5 \%$ カゼインを $20 \%$ カゼインに切りかえて急制な 成長をおこさせてす貧血はみられなかったが，これは網 赤血球数の急激な增加のためであろう。したがって, 低 たん白貧血はへモグロビン合成というょりは赤血球形成 に関連のある因子であると考えられる。この実験で明ら かなことは鉄欠乏性貧血は，その期間やたん白摄取レベ ルKよって造血の様態が複雑であり, 貧血の種類で網赤 血球数の性質が異なるといら報告35) すり，今後，種々 の栄養秦欠乏の組合わせで実质を行なら必要がある。

$$
\text { 要 約 }
$$

鉄およびたん白欠乏の単独と同時の成長期ラット血色 素合成におよばす影橥をみた。生後 3 週踰の倠ドンリ= ーラット（55匹）を $20 \%$ および $5 \%$ カゼイン食群の二 つに分け,これをさらに対照群と鉄欠乏群に分けて3週 間飼育した。毎週 1 回体重測定のほ加尾静脈より 0.1 $\mathrm{m} l$ 程度採血を行ない一モグロビン量，へマトクリット 値, 網赤血球数, 血墏たん白を湘定した。3 週後一部を 腋下採血屠殺して，血漿および肝㦹の鉄含量を湘定し た。残りの群を 1 週間鉄またはたん白食投与による回復 の影贅をみ，以下のよらな結果を得た。

1）铁欠乏食による体重の增減は鉄入りの対照に比へ 
変化がなかった。

2）血中へモグロピン量 (Hb)，ヘマトクリット值 (Ht) は $20 \%$ カゼイン食では铁欠乏群に $\mathrm{Hb}, \mathrm{Ht}$ の有 意の低下がみられたが，5\%カゼイン食では铁欠乏群で す $\mathrm{Hb}, \mathrm{Ht}$ の低下はみられなかった。平均赤血球色素 淹度 (MCHC) はいずれの群にす大きな差はみられなか った。

3）血䈋および肝の鉄含量について $20 \%$ カゼイン食 の鉄欠乏と回復群が低く，5\%カゼイン食群は血獎鉄が 高い㑯向にあった。

4) 網亦血球数は加跲にともない低下し，20\% カゼイ ン食の铁欠乏群で上昇を示し，铁投与によりさらに上昇 した。5\%カゼイン食では網赤血球数は低下し，铁欠乏 や鉄投与の影数はみられずたん白投与によって上昇し た。

5) 成長期におけるたん白欠乏では筫血はおこりにく く，良好な成長を示す栄菜状態で鉄欠乏性筫血がギこる ことがわかった。これは成長による铁要求性の增加と考 えられ，たん白投与による網赤血球の増加とともに被雑 な造血機構が討議された。

本研究を遂行するにあたり，多大のご助言ならびにご 援助をいたたいた国立公衆衙生院栄羕生化学部佐々木敦 子研究員に深く感䛠いたします。

\section{文榊}

1) IAEA/USAID/WHO : WHO Technical Report Series No. 580 Control of Nutritional Anemia with Special Reference to Iron Deficiency, WHO, Geneva (1975)

2）野村 茂: 生活と筫血, P. 94 (1979), 医海薬出版 (東京)

3) Fomon, J. : Infant Nutrition (2nd Edition) (1978), Saunders (Philadelphia)

4) 中尾喜久：貧血のすべて(内科シリーズ, No. 14), p. 70 (1975), 南江堂 (東京)

5) Williams, W.W. : Hematology (2nd Edition) (1977), McGraw-Hill (New York)

6) 梶本雅俊, 鉿木妙子, 近藤雅雄, 木村秀子, 長谷 川藮子, 浦田郡平, 丹羽源男: 第34回日本栄養食 糧学会譜演要旨集, P. 82 (1980)

7) Dallman, P.R. :J. Nutr., 97, 475 (1969)

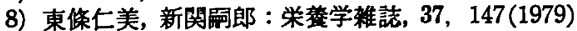

9) 浦田郡平, 暒本雅俊, 鈴木妙子, 近藤雅雄, 木村 秀子，佐々木敦子：昭和53年度, 日米医学協力計 画栄菜異状部会報告書, 85 (1979)
10) McCall, M.G., Newman, G.E., O'brien, J.R.P., Valberg, L.S. and Witts, L.J. : Brit. J. Nutr., 16, 297 (1962)

11) McCall, M.G., Newman, G.E., O'brien, J.R.P. and Witts, L.J. : Brit. J. Nutr., 16, 305(1962)

12）吉野芳夫, 今井芳恵, 島田洋一, 田中勝㭽, 渡辺 一征, 田村盈之輔：栄養と食棏，26，539（1973）

13）白木啓三，久岡文子：第26回栄養食棏学会要旨集, 255 (1977)

14) Viteri, F.E., Alvarado, J., Luthringer, D.G. and Wood, R.P. : Vitam. and Horm., 26, 573 (1968)

15) Fondu, P., Muller, C.H., Mozes, N., Neve, J., Steirteghem, A.V. and Mandelbaum, I.M. : Am. J. Clin. Nutr., 31, 46 (1978)

16) Duncombe, M., Bollin, T.D. and Davis, A.: Am. J. Clin. Nutr., 32, 553 (1979)

17) Conrad, M.E., Foy, A.L., William, H.L. and Knospe, W.H. : Am. J. Physiol., 213, 557 (1967)

18) Viart, P. : Am. J. Clin. Nutr., 30, 334 (1977)

19) Viart, P. : Am. J. Clin. Nutr., 31, 911 (1978)

20) Lynch, S.R., Becker, D., Settel, H., Bothwell, T.H., Stevens, K., Metz, J. : Am. J. Clin. Nutr., 23, 792 (1970)

21）梶本雅俊, 中川一郎, 名取靖郎：栄養と食棏, 32, 123 (1979)

22) International Committee for Standardization on Hematology: Brit. J. Haemat., 13, 71 (1967)

23) International Committee for Standardization in Hematology : Blood, 37, 598 (1971)

24) Layrisse, M., Torres, C.M. and Roche, M. : Am. J. Clin. Nutr., 21, 1175 (1968)

25) Amin, E.K. and Hegsted, D.M. : J. Nutr., 101, 927 (1971)

26）吉野芳夫, 平松芳子, 柳下 晃, 寺戸国昭 : 栄菻 と食糧, 24, 206 (1971)

27) 坂本元子, 石井荘子 : 栄羡学雑誌, 28, 133 (1970)

28）久岡文子, 佐川寿栄子, 三木健寿, 白木啓三 : 栄 蘶と食糧，31，59 (1978)

29) 白木啓三, 久岡文子：栄愁之食糧, 25,431 (1972)

30) 白木啓三，久岡文子，佐川寿栄子 : 栄盖と食粞, 29, 283 (1976)

31) Viart, P. : Am. J. Clin. Nutr., 30, 349 (1977)

32）白木啓三 : 栄鍫と食棏，25，475 (1972)

33) Fondu, P., Mandelbaum, I.M. and Vis, H.C. : Am. J. Clin. Nutr., 31, 717 (1979)

34) Ward, C., Saltman, P., Ripley, L., Ostrup, R., Hegenauer, J., Hatlen, L. and Christoper, J. : Am. J. Clin. Nutr., 30, 1054 (1977)

35) Black, C., Glass, J., Nunez, M.T. and Robinson, S.H. : J. Lab. Clin. Med., 93, 645 (1979)

(昭和 55 年 8 月 14 日受理) 